\title{
The Practice of Humanistic Buddhism for the Indonesia's National Integrity
}

\author{
Wiliem $^{1}$, Rustono Farady Marta ${ }^{2}$, Sulaiman Girivirya ${ }^{3}$ \\ ${ }^{1,2}$ Master of Communication Science, Bunda Mulia University, North Jakarta \\ ${ }^{3}$ College of Religious Studies, Mahidol University, Salaya, Thailand \\ Email:wiliemlesmana@yahoo.com
}

\begin{abstract}
Abstrak
Berada di tengah masyarakat Indonesia penuh keragaman sehingga perlu adanya rasa toleransi dan menghormati perbedaan tersebut agar tetap dapat menjaga keutuhan bangsa, dimana hal ini selaras dengan ajaran Buddhis yang juga mengajarkan kebaikan untuk dapat hidup berdampingan dalam masyarakat sehingga akan muncul kondisi damai dan sejahtera seperti yang didambakan, maka cara berkomunikasi seperti yang tertuang pada teks pesan Waisak 2020 Sangha Theravāda Indonesia ditinjau menggunakan teori komunikasi Buddhis sebagai bagian dari teori komunikasi yang berasal dari timur serta semiotika Buddhis untuk membedah makna dari teks tersebut agar dapat diamalkan dalam kehidupan keseharian. Hasil temuan dari analisis pada teks tersebut yaitu menunjukkan bahwa setiap intisari paragraf pada teks pesan Waisak 2020 Sangha Theravāda Indonesia memiliki pola penyampaian komunikasi berbasis Buddhis yang bermanfaat tidak hanya bagi umat Buddhis namun bagi masyarakat luas tentang pentingnya mengamalkan ajaran cinta kasih dalam membangun semangat persaudaraan demi menjaga keutuhan bangsa Indonesia.
\end{abstract}

Kata Kunci: Kemanusiaan, Komunikasi Buddhis, Persaudaraan, Semiotika Buddhis, Toleransi

\begin{abstract}
In the midst of Indonesian society which is full of diversity, so there needs to be a sense of tolerance and respect for these differences in order to maintain the integrity of the nation, where this is in line with Buddhist teachings which also teach to be able to live in people's lives so that the desired state of peace and prosperity will emerge. communicate as stated in the text of the 2020 Vesak message of Sangha Theravāda Indonesia is reviewed through the use of Buddhist communication theory as part of communication theory originating from the east and Buddhist semiotics to dissect the meaning of the text so that it can be practiced in daily life. The findings from the analysis of the text show that each paragraph in the text of the 2020 Vesak message of Sangha Theravāda Indonesia has a Buddhist-based communication delivery pattern that is beneficial not only for Buddhists but for the wider community about the importance of practicing the teachings of love in building a spirit of fraternity in order to maintain the integrity of the Indonesian nation.
\end{abstract}

Keywords: Buddhist Communication, Buddhist Semiotics, Fraternity, Humanity, Tolerance

\section{INTRODUCTION}

Indonesia has various religions, ethnicities, tribe, and cultures that should be seen as a form of wealth and national identity in order to increase the unity and integrity of the Indonesian people. The mixing of these four things into one can lead to peace and beauty, as 
a form of practicing the implementation of the motto Bhinneka Tunggal Ika and practicing the third and fifth precepts of the Pancasila state philosophy in the life of the nation and state. Indonesia's vast geographical condition and rich culture make us have to admit that in addition to having positive potential, this country also has a large potential for conflict.

Tolerance in diversity in Indonesia has been stated in the state motto that has been made by the founding father in the hope that it will create such ideal living conditions to be able to maintain harmony in the life of the nation and state so as to avoid division (Marta, 2017). Various ways to be able to introduce this motto are necessary to the next generation from an early age, both conventionally and by using technology such as through animated children's films that show the existence of diverse living conditions and Indonesian cultural identity (Sya et al., 2020).

As the nation's next generation, we are expected to be able to overcome this diversity by adhering to the values of tolerance, tolerance, promoting the principles of unity and social care, and applying human values in daily life. These human values include virtue, truth, compassion, peace, and non-violence, which are universal and can be practiced in everyone's daily life which must be carried out as a form of unity (Jumsai \& Na-Ayudhya, 2008). There needs to be wisdom and adaptation to the local local culture in terms of time and situation so that the practice of human values can be well received so that it does not become in vain.

The practice of human values is also in line with the moral teachings of various religions which include human relations with oneself, relationships between humans both in the social and natural environment, as well as human relationships with God (Nurgiyantoro, 2010). Cultivating universal human values in the wider community is also the goal of moral education, with the aim of fostering fraternity between humans as individuals and social groups.

In Buddhist teachings, ethics related to tolerance have also been taught, namely love (mettā) and compassion (karunāa) so that they can establish a sense of fraternity among human beings. Germer \& Siegel (2012) revealed that the practice of compassion can provide a valuable solution to ending suffering, which can be used to improve relationships, reduce conflict, maintain unity and harmony, and recognize the impermanence of this social experience.

Instilling a sense of tolerance between religious communities in each individual can be assessed as a social mechanism that is carried out in responding to religious diversity and plurality in everyday life (Faridah, 2013). Maintaining good communication patterns with a humanistic approach will also be able to create a harmonious atmosphere and a good individual personality as a form of tolerance between fellow humans (Nidyansari, 2018). Likewise, Buddhist teachings teach everyone not to impose their will and accept every difference in real life as a process to build a sense of fraternity.

The existence of pluralism is a continuation of the concept of tolerance and moral coexistence, and requires a correct and deep understanding, but until now the concept of pluralism in Indonesia is often misinterpreted and even used for certain purposes which are considered to deviate from basic doctrines and can disrupt the peaceful life of religion (Dzakie, 2014). So as good citizens, we must instill a high level of tolerance so that we can tolerate each other and make Indonesia a closely united country. 
The spirit of pluralism as a moral concept that must be owned by every citizen, as an appreciation of differences and heterogeneity, as well as an attitude of acknowledging differences that must be applied to include all parties in diversity. The understanding of pluralism invites us to see that all religions essentially teach about morality and truth, it's just that the way and way of conveying the teachings of goodness is different. The same thing has also been conveyed by Hamdun (2018) which states that pluralism is not just a fact or condition that is plural, plural or more but is also reflected in an attitude of mutual respect, respect, nurturing, even improving or enriching the situation for the better.

In addition to tolerance for diversity, solidarity in coexistence arises from the awareness of each individual. This movement was born thanks to a person's sense of sensitivity and concern in order to achieve justice without tucked in the elements of infiltration of other agendas (Koli \& Sadono, 2018).

Buddhism as a teaching that is relevant to the conditions of today's society can be used as a way of life because Buddhism shows human beings how to cultivate maturity and wisdom in order to understand themselves and the environment in which they live. Starting from how to deal with problems and various events that arise in everyday life to how a person develops a good attitude towards his social life so that the relationship between oneself and the environment becomes better.

According to population census data by BPS in 2010, the Buddhist community in Indonesia is only $0.72 \%$ or of the total population of Indonesia so that it is categorized as a minority group, but the role of Buddhists in maintaining national unity can be seen clearly and has been felt by many people. all groups of society (Kadir, 2014). As for Buddhism as the fourth oldest religion in the world with more than 520 million followers worldwide, there are many literary texts and discourses that lead to the teachings of peace, harmony, wholeness, and fraternity, so it is interesting to look at from the point of view of communication as a way of communicating. in spreading the teachings to the wider community.

Buddhist teachings have the flexibility and resilience to allow adaptation to the changing needs of different levels of human beings, who selflessly integrate into different races and cultures (Tan, 2014). This can be proven by referring to several sources of Buddhist teachings which mainly discuss the practice of loving kindness, building a sense of fraternity, or not imposing Buddhist teachings on others.

Like the majority of the world's major religions, Buddhism is also divided into a number of different traditions but still share a common set of fundamental beliefs: goodness. Buddhist teachings themselves also emphasize the importance of a person to rely on one's own efforts to achieve a good goal and teach that each individual should have a sense of tolerance for beliefs and others also give love and compassion to all living beings.

The spiritual technique that aims to pass through thought and meaning to achieve enlightenment is one of the hallmarks of Buddhist teaching by contemplating every condition of the worldly life one goes through and reflecting inwardly. These worldly conditions as defined in Buddhist teachings include three main things, namely impermanence (anicca), suffering (dukkha), and corelessness (anatta) which are the basic characteristics of Buddhism. give real meaning to life until it finally reaches the highest liberation (Littlejohn \& Foss, 2012). 
Furthermore, these characteristics also affect the Buddhist communication approach where in general, what distinguishes the Buddhist point of view in the context of communication is regarding language and verbal communication, both of which are characterized by practicing a middle way that avoids extremes. From the point of view of Buddhist communication theory, there are five main presuppositions related to the ideal social order of society, namely: (1) human beings are supreme, (2) reason and understanding of compassion rather than blind dogma should guide human actions, (3) human beings must be pragmatic in their behavior, (4) all forms of violence must be eliminated, and (5) peace and harmony are ideals that sustain society.

One of the Dhamma doors in the Mahāyāna Buddhist school that is well known and in tune with modern times is Humanistic Buddhism which encourages individuals to develop and integrate the fundamental Buddhist teachings of tolerance, love, compassion, joy, and equanimity into their daily lives. for the benefit of all beings (Richard L. Kimball, 2000). The goal of this Dhamma door practice is to build a harmonious society by helping those in need, transmitting virtue from within ourselves to our families, communities, nations, and even more broadly throughout the world.

The focus of Humanistic Buddhism in practice is more on worldly problems than on how to be free from the worldly; about caring for the living rather than the dead; about benefiting others rather than benefiting oneself; and about universal safety rather than cultivating by oneself (Guangliang, 2019). Until now, this practice also continues to be aligned with the development of modern thought so that it can be more easily accepted by the wider community.

Zengwen (2019) also reveals that coordination and harmony between monastic members and lay people is an important foundation in the process of developing Humanistic Buddhism, but it is more important to have mutual trust and respect between the two. A major breakthrough in terms of harmonization of monastic relations and lay people to jointly build a Buddhist order and organization is also very much needed so that it is hoped that the teachings of Humanistic Buddhism will continue to develop and be more in line with the needs of modern society. Thus, it will help develop the local monastery's capabilities in terms of management, Dhamma dissemination activities, various cultural efforts, and educational efforts.

Pornchai Sripakdee (2017) reveals that based on Buddhist ethics, any form of communication must be based on ethics because it requires an ideal life where there is no suffering. As long as all processes and ways of communication follow the human way of life, the world's complex problems will be solved. In line with the issue of ethics in the communication process, Roy \& Narula (2017) also said that Buddhism is not only seen as a religion but also as a guide for daily life. Its spread can be seen from the existence of culture and good communication processes to pave the way for someone to freedom.

Many research articles have researched Buddhism in Indonesia, but some of them are historians who only specifically make research referring to the history of the origin of Buddhism from the time of the ancient kingdoms to its development in Indonesia today. So far, there have not been many studies that have raised Buddhist teachings from the point of view of communication as a reference in building national unity and integrity, therefore, in 
this article, it is hoped that this article will be able to dig deeper into the meaning of the 2020 Vesak message delivered by the Sangha Theravāda Indonesian (STI) so that can be practiced in daily life for the wider community and viewed from the point of view of communication to establish fraternity in the life of the nation and state.

Some communication experts such as Mortensen and Sereno in (Saputera, 2014) are of the view that the communication model is an ideal explanation of what is needed for communication to occur. This communication model represents important characteristics and eliminates unnecessary communication details in the real world. Then Gordon Wiseman and Larry Barker in (Mulyana, 2007) also revealed three communication functions, namely helping to explain the communication process, displaying visual relationships, and finding and overcoming communication bottlenecks.

The communication model in Buddhism is very different from the modern communication model from the west (Aristoteles) as described by communication experts in general, where the message conveyed is more directed to individual inner progress based on the fundamental teachings of Buddhism. This communication model is based on the "Dantabhūmi-sutta" section of the Majjhima nikāya which deals with the various biological, psychological and behavioral goals of the recipient to enter the path of holiness.

The models identified in the discourses of Gotama Buddha show that listeners should not go to extremes but adapt to behave in the middle way of life, and these models place listeners and communicators actively and identify them as people with broad knowledge and wisdom, so that they can create harmonious conditions in everyday life based on mutual understanding of each other.

Based on the above background, this paper examines the communication model in Buddhism contained in the text of the 2020 Vesak message by the Sangha Theravāda Indonesia (STI) to increase a sense of fraternity and maintain the integrity of the nation, starting with elevating the basic teachings of Buddhism and then reviewing it more deeply from the point of view of the point of view of communication is Buddhist semiotics and is discussed based on the concept of Humanistic Buddhism. It is hoped that the interpretation of the meaning of the text can be practiced by the wider community in daily life to support the integrity of the Indonesian nation, and to better understand the communication model in Buddhism to convey universal truth teachings that are dissected using Buddhist semiotics.

\section{METHODOLOGY}

A qualitative approach with an interpretive paradigm will be used in this study and is based on Buddhist communication theory as a basis for analysis to obtain sharper and more in-depth study results. As also explained by (Mulyadi, 2013) that qualitative research is a research method that represents an understanding of naturalism (phenomenology), so that it can make in-depth, systematic, factual and accurate descriptions, descriptions, and meanings about various characteristics, facts, and relationships. between the variables studied.

The interpretive paradigm can help researchers to look deeper into the reality of social life that is happening (Anggraini, 2017). When there is new information obtained through this paradigm, it can decide whether the reality is only a symbol or an idea that is deliberately generated or is it a fact of a social problem. 
Rorong (2020) explains that the study of phenomenology is considered as an integral part of individual experience, learning, and deep meaning. This phenomenological approach also views from the subject's point of view as an instrument for certain phenomena. In this article, phenomenology tries to reveal the meaning of the concept of the text of the Vesak message in relation to being well received in society and can be practiced for the realization of the integrity of the nation.

The data source in this article is the entire text of the Vesak message by Sangha Theravāda Indonesia in commemoration of the 2564 B.E./2020 Vesak celebration which falls on Thursday 7 May 2020, but because the whole world is facing the Covid-19 pandemic, the Vesak message is usually circulated to all over Indonesia in the form of printed pamphlets are now made in digital form and can be accessed through the official website of the Sangha Theravāda Indonesia.

This research article uses Buddhist semiotics as a scalpel to examine the meaning of the text of the 2020 Vesak Message delivered by Sangha Theravāda Indonesia, in which each subheading will make a paragraph digest to draw conclusions about Buddhist teachings to be practiced in daily life, besides that the results of the study also refer to communication theory. Buddhists to understand more about the communication model. Semiotics has different resources so that it produces various interpretations of the signs on the object so that the meanings that appear will also be different (Januarti \& Wempi, 2019).

Buddhist thought regards language as the main tool in constructing and presenting an extraordinary reality. Language that describes the world has no absolutely absolute value, because language is an instrument of false knowledge which creates a perceived reality in a state of general consciousness by means of classifying and conceptualizing perceptual data and linguistic expressions of their meaning.

Semiotic attention in Buddhism is embedded in intellectual and religious discourse, starting with the idea that the world is not as it seems and thus requires a more accurate understanding of self and reality. This will lead to ongoing discussions about the status of language and representation, and about the possibilities and methods of knowing reality beyond imagination; such special knowledge is explicitly defined as enlightenment (Rambelli, 2013).

In addition, Buddhism also developed a special semiotic terminology, but unfortunately it is not well understood in its semiotic specificity, because it tends to be studied in linguistic terms, philosophy of language, or academically more generally. Due to the absence of a single semiotic theory that covers all the same Buddhist traditions, it is almost impossible to describe a "Buddhist semiotics" normatively, but there are several local semiotic theories (which are similar to the field of contemporary semiotics) covering ontology, the nature of signs, language, visual and artistic representations, semantic systems, and implementations to support the depiction of semiotics in Buddhism. So, for Buddhists, semiotics is directly relevant to salvation which is the key but is often overlooked even by Buddhists.

Furthermore, Rambelli (2013) also reveals that Buddhist semiotic ideas and practices show many differences, because they develop in various cultural, historical, and social contexts. Buddhist teachings have established two fundamentally different types of semiotics, 
namely: (1) concerned with what is commonly known as ordinary semiosis, and (2) for describing interactions with reality in an altered (meditative) state of consciousness.

The data validity technique in this article uses theoretical triangulation to reduce the subjectivity of researchers in reviewing and presenting research results. Triangulation of this theory can increase the level of insight as long as researchers can thoroughly test theoretical knowledge from the results of data analysis obtained.

\section{RESULT AND DISCUSSION}

The main holiday that is always awaited and commemorated by all Buddhists throughout the world is the Vesak Day which commemorates the occurrence of three great events of Gotama Buddha, namely the birth of Prince Siddhattha, the ascetic Gotama's attaining complete enlightenment, and the attainment of final liberation (death) of Gotama Buddha (Susilawati \& Ekwandari, 2012). The three events occurred on the same day, namely on the day of the full moon of the fourth month of the lun(Tobgay, 2018)ar calendar even though the year and place of the event was different.

This privilege is interpreted by Buddhists as a great event full of meaning and blessing which is expected to give hope and become a role model for everyone (Tobgay, 2018). Various commemorations to the form of celebration in each place vary according to the culture of each country, but they still have the same essence, namely to imitate the noble nature of Gotama Buddha and practice His teachings of truth for the benefit and happiness of all beings without exception.

The Vesak Day in 2020 was commemorated in a different way than usual due to the Covid-19 pandemic that spread throughout the world. Many monasteries hold a series of ritual events, Dhamma classes, to virtual events that can facilitate Buddhists, especially in Indonesia, to continue to interpret Vesak commemorations even though they are only in their respective homes.

Just staying at home does not mean not doing something that is not beneficial to many people, but it can save the lives of many people from being exposed to the Covid-19 virus so that they can break the chain of spread and this pandemic is expected to end more quickly. This of course can also be a way of practicing love (mettā) for others as a form of practicing Buddhist teachings in social life.

This practice is not only can be done by Buddhists, but also by all human beings to achieve the common goal of an early end to the pandemic and reduce the number of victims who have the possibility of exposure to the virus Covid-19. Teachings of kindness to fellow human beings concerned also in harmony with what is taught by Gotama Buddha since 2600 years ago. Therefore, every element of society should take part in this good practice for the great benefit of all human beings.

Every year, Sanggha Theravāda Indonesia publishes the Vesak message with a different theme to serve as a form of reflection on the meaning of the great Vesak event and is usually echoed once a month before the Vesak day itself. The theme for the 2020 Vesak commemoration, namely Real Fraternity, the Basic Integrity of the Nation, is considered relevant in the context of addressing various problems related to various kinds, socio-cultural conditions, and current social conditions, especially to maintain the integrity of the nation. 


\section{BUILDING INTEGRITY OF THE NATION}

In the text of the 2020 Vesak message, referring to one of the verses in the Karaniya Mettā Sutta, it is then described in the context of building fraternity in order to maintain the integrity of the Indonesian nation. The analysis of the results of the study using elements of Buddhist semiotics on the Vesak message above will be described in the following paragraphs.

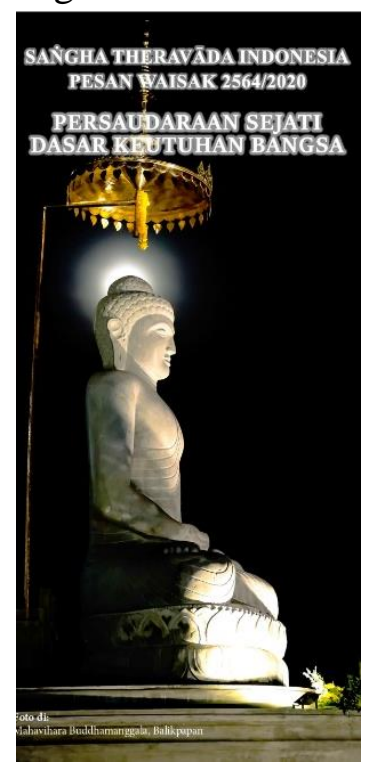

Source: 2020 Vesak Message of Saṅgha Theravāda Indonesia, (2020).

Picture 1. Pamphlet Cover of 2020 Vesak Message Text of Sangha Theravāda Indonesia

Judging from the cover image of the printed pamphlet above, it can be identified that there are 3 main elements, there are the Buddha statue in a meditative position with a golden umbrella above the head and the beam of light leading to the image, the full moon with white light shining above the image, and the title of the Vesak message and the theme of the 2020 Vesak commemoration are white on a black background. The three of them look visually compatible and provide deep meaning regarding the message to be conveyed in it, namely Buddhist teachings as the basis for maintaining the integrity of the nation.

The harmony in the image is a form of visual and artistic representation of Buddhist art and culture in Indonesia in presenting a feeling of harmony in the hearts of every person who sees it. It can also be reassuring so that it is hoped that you can see all the realities that exist in the world more openly and realistically.

Visual representation can be said to have meaning for someone as a form of motivation to participate (Lane et al., 2020). Furthermore, Sankey (2006) reveals that visual representations are often used to correct communication errors that fail to convey a concept completely in conventional methods. In this case, Fauzi \& Fasta (2020) also states that visuals in the media have the power to control representations where the influence is cultural and psychological.

From the visual image, it also appears that the existing elements represent the peace aspect so that it is in line with the theme raised and is suitable to be used as the cover page for the text of the Vesak message. The use of images of Buddha images with the Borobudur 
version reflects that Buddhist teachings have entered and developed to help maintain harmonious living conditions in Indonesia.

Understanding life in real life allows us as humans to emphasize the importance of basic human values that contribute to contentment, harmony, and peace to this day. Because there are still many individuals who think that life is still filled with various forms of frustration and anxiety, where current material and technological advances have not been able to completely solve human problems perfectly, therefore the basics of Buddhism can be applied to every line of life in order to obtain peace.

\section{THE REAL FRATERNITY}

In the first subheading, which raises about real fraternity, it explains the life of brothers and sisters in the midst of harmony in accordance with the motto of the Indonesian nation, namely Bhinneka Tunggal Ika. This is also in line with Buddhist teachings in fostering fraternity with love and compassion.

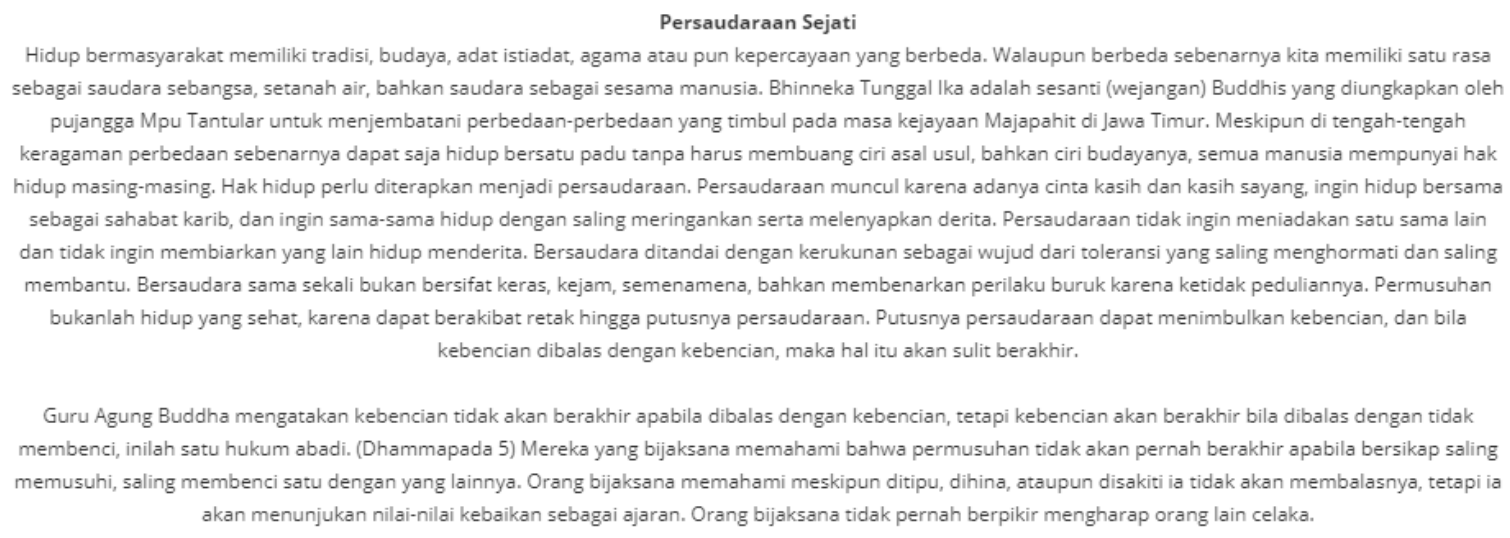

Source: 2020 Vesak Message of Sangha Theravāda Indonesia, (2020).

Picture 2. Subheading"The Real Fraternity" in the 2020 Vesak Message of Sangha Theravāda Indonesia

Table 1. The results of the analysis of the subheading "The Real Fraternity" in the 2020 Vesak Message of Sañgha Theravāda Indonesia

\begin{tabular}{|c|c|c|c|}
\hline No. & Pieces Digest Paragraphs & Buddhist Semiotics & $\begin{array}{c}\text { Buddhist Communication } \\
\text { Theory }\end{array}$ \\
\hline 1 & $\begin{array}{l}\text { Community life certainly has } \\
\text { different traditions, cultures, customs, } \\
\text { religions, and even beliefs. Despite } \\
\text { the manifold differences, it remains } \\
\text { possible to live peacefully without } \\
\text { having to remove the original } \\
\text { features, including a cultural nature, } \\
\text { because all human beings have the } \\
\text { right to their own life. }\end{array}$ & Semantic System & $\begin{array}{l}\text { It's hard to be born as a } \\
\text { human; Humans are beings } \\
\text { who have the highest } \\
\text { consciousness. }\end{array}$ \\
\hline
\end{tabular}




\begin{tabular}{l}
\hline \hline $\begin{array}{l}\text { Because of the love and affection that } \\
\text { arise fraternity, where they want to }\end{array}$ \\
$2 \quad \begin{array}{l}\text { live together as a close friend to be } \\
\text { able to relieve each other and } \\
\text { eliminate suffering. }\end{array}$ \\
$\begin{array}{l}\text { Fraternity does not want to exclude } \\
\text { and allow others to live in suffering. } \\
\text { Enmity is not a healthy life, because } \\
\text { it can result in fractures and the } \\
\text { collapse of fraternity. }\end{array}$
\end{tabular}

Source: Research Processing Results, (2021).

Seen in table 1 above, the paragraph that discusses real fraternity in Buddhist teachings can be divided into three more in-depth essence pieces. All three can be viewed from the three elements of Buddhist semiotics, namely the semantic system, ontology, and implementation, which are then linked to Buddhist communication theory.

The semantic system shows the use of words or sentences that lead to meaning as the basis for using language in the communication process (Ramadani, 2020). Logical semantics is one type of semantics that examines the meaning system seen from logic and then refers to the study or interpretation of text, speech, and visuals (Ginting \& Ginting, 2019).

In the essence of the first paragraph, it discusses community life with diversity so that it has different traditions, cultures, customs, religions, and even beliefs but can live in unison without the need to discard the characteristics of its origin, so that it can be viewed from the category of logical semantic systems for further study. carry on. In the type of semantic logic, the message conveyed in this section enters into the interpretation of Buddhist teachings as a guide to living in a society with a high level of diversity so that it can form unity regardless of status and every human being has the right to live.

The essence of this paragraph can be studied by referring to the elements of Buddhist communication theory which discusses the very preciousness of being born as a human being as a being who has the highest level of consciousness among others. Just as in the vast ocean there is a blind turtle that will come to the surface once every hundred years and then when it appears must put its head in a circle that is tossed around with the current of water, so also the parable of the difficulty of being reborn as a human was conveyed by Gotama Buddha.

Ontology discusses what you want to know about the theory of something that "is" or in other words examines how the nature of the object under study produces knowledge (Bahrum, 2013). Furthermore, Zainnudin (2013) reveals the problems contained in the ontology include what is the nature of science, what is the nature of truth and reality that is inherent in that knowledge, regardless of what and how things exist (being).

Kattsoff \& Soemargono (1986) divides ontology into three parts: simple ontology, quantitative and qualitative ontology, and monistic ontology, all of which have special characteristics as a way of looking at a problem. It is explained that the simple ontology sees 
everything in its natural state and as it is which makes a person able to be more realistic when facing diversity in the social order of society.

In the essence of the second paragraph, which discusses the beginning of the emergence of a sense of fraternity originating from the existence of love and compassion so that they can together escape suffering, it will be viewed from the perspective of a simple ontology. The meaning conveyed explains the truth of Buddhist teachings as a basis for knowledge to see various realities in real life so that they can live together in harmony until they achieve absolute freedom.

Fraternity and enmity are two opposites but also interrelated. By awakening a sense of fraternity among human beings, it is hoped that harmony and unity can occur which also causes peace in the social environment in accordance with Buddhist teachings which prioritize the interests of the people and do not impose their will.

The importance of having reason and understanding compassion for all beings without limits as a form of practice of Buddhist teachings in everyday life that can be practiced by every individual. Virtue embedded in a person will spread the message of goodness and bring benefits to many people. Therefore, true fraternity will emerge thanks to the support of every human being who desires peace in the midst of a society that has a high level of diversity and the Buddhist teachings conveyed in the Vesak message are very relevant to today's humanistic practice.

Overall, this subheading explains the importance of practicing love and compassion as a foundation for building fraternity in today's diverse society. Eliminating feelings of resentment and hostility is also important so that various groups can live side by side and synergize in creating peace as well as maintaining the unity and integrity of the nation.

\section{BASIC INTEGRITY OF THE NATION}

In this subheading, it describes Buddhist teachings as the basic foundation for the integrity of the nation, the key is to apply honesty in daily life. The practice of honesty is very much needed to avoid conflicts of interest, so as to achieve the goal of fostering a complete nation's life.

\footnotetext{
Dasar Keutuhan Bangsa

Keutuhan dalam kehidupan bermasyarakat sepenuhnya tergantung pada sikap saling mempercayai, bukan saling mencurigai, kuncinya adalah kejujuran, Hendaknya kejujuran diri dikembangkan pada diri sendiri, demikian juga terhadap orang lain. Kejujuran itu berasal dari kewajaran, apa adanya, bukan sikap berpura-pura, berbohong, apalagi oportunis. Kejujuran merupakan sebuah sikap dasar yang patut diperhatikan bagi mereka yang menginginkan suasana saling menghargai, saling menghormati untuk menimbulkan kedekatan atau keutuhan dalam suatu komunitas bangsa.

Ajaran agama memengaruhi kondisi psikologis manusia, kedalam kondisi emosi yang paling dalam. Kondisi emosional keagamaan yang tidak tepat sesuai ajaran agama, kerap dijadikan sebagai alat penentu bagi mereka yang mempunyai kepentingan sesaat dan yang merasa paling benar. Sedangkan yang lainnya dianggap salah, padahal realitanya, kebenaran bukanlah milik segelintir orang. Sebab ada kebenaran bersifat universal yang terdapat dalam ajaran agama tersebut. Karena itu pada saat memegang kebenaran universal harus disertai nilai kejujuran, sebagai penentu terciptanya keutuhan hidup bermasyarakat, bukan sebaliknya seperti pembenaran kekeliruan, hal itu akan menyeret masuk masyarakat ke berbagai konflik kepentingan sempit. Penerapan kejujuran dan kebenaran universal sesuai ajaran agama akan membangun sebuah keutuhan bangsa yang sangat diperlukan bagi keberlangsungan bangsa dan negara.
}

Source: 2020 Vesak Message of Sangha Theravāda Indonesia, (2020).

Picture 3. Subheading "Basic Integrity of The Nation" in the 2020 Vesak Message of Sangha Theravāda Indonesia 
Table 2. The results of the analysis of the subheading "Basic Integiry of The Nation" in the 2020 Vesak Message of Sañgha Theravāda Indonesia

\begin{tabular}{|c|c|c|c|}
\hline No. & Pieces Digest Paragraphs & Buddhist Semiotics & $\begin{array}{c}\text { Buddhist Communication } \\
\text { Theory }\end{array}$ \\
\hline 1 & $\begin{array}{l}\text { Honesty is a basic mindset that } \\
\text { deserves attention for those who want } \\
\text { an atmosphere of mutual respect, } \\
\text { mutual respect in order to establish } \\
\text { closeness or integrity in a national } \\
\text { community. }\end{array}$ & Epistemology & \multirow[b]{2}{*}{$\begin{array}{l}\text { Human beings must have a } \\
\text { pragmatic behavior. }\end{array}$} \\
\hline 2 & $\begin{array}{l}\text { Because there is a universal truth in } \\
\text { the teachings of the Buddhist } \\
\text { religion, the application of universal } \\
\text { honesty and truth will build the } \\
\text { integrity of the nation which is } \\
\text { indispensable for the survival of the } \\
\text { nation and state. }\end{array}$ & Implementation & \\
\hline
\end{tabular}

Source: Research Processing Results, (2021).

Referring to table 2 above, this paragraph discusses true brotherhood in Buddhist teachings divided into three sections with a more detailed essence. The three paragraphs can be viewed from two elements in Buddhist semiotics, namely epistemology and implementation, each of which is then linked to Buddhist communication theory.

The essence of the first point paragraph discusses the practice of honesty as a basic attitude to create unity in one nation's community, which can be viewed from the epistemology of Buddhist semiotics. The branch of philosophical epistemology as the basis for analyzing this first piece of text describes honesty as a way of thinking in Buddhist practice to carry out daily life that will produce great benefits for the welfare of many beings.

The essence of the second paragraph shows the existence of universal truth teachings and their application must be accompanied by the value of honesty in order to create the integrity of social life. This is a form of implementation of Buddhist teachings, namely honesty (sacca) which sees real life conditions and can convey reality as it is to others, and is expected to bring good benefits to every member of society.

The nature of honesty is also seen as an ethical practice in order to live in harmony, without suspicion in society, for example acknowledging the existence of diversity then honestly admitting it and accepting it without causing suspicion that can divide life. This practice is not only beneficial for oneself but also for others and even the wider community.

Pragmatic behavior in Buddhism shows that humans need to have a simple life, reduce unnecessary desires so that they can make savings, to humility so that they can more easily escape from worldly suffering. If this trait can be instilled in oneself, then it is not impossible that life becomes simpler and all its goals can be more easily achieved.

This subheading reveals the importance of applying the nature of honesty and universal truth according to Buddhist teachings in order to build a nation's integrity which is indispensable for the sustainability of the nation and state. So every individual should be able 
to contribute to each other based on the teachings of goodness as the obligation of every citizen to maintain the existence of the nation in the future.

\section{MUTUAL COOPERATION AND THE NATION'S STRUGGLE}

This subheading consists of two main parts, namely mutual cooperation and the struggle of the nation. Both have a relationship with each other, so the meaning becomes interesting to be studied more deeply separately so that it can be practiced better.

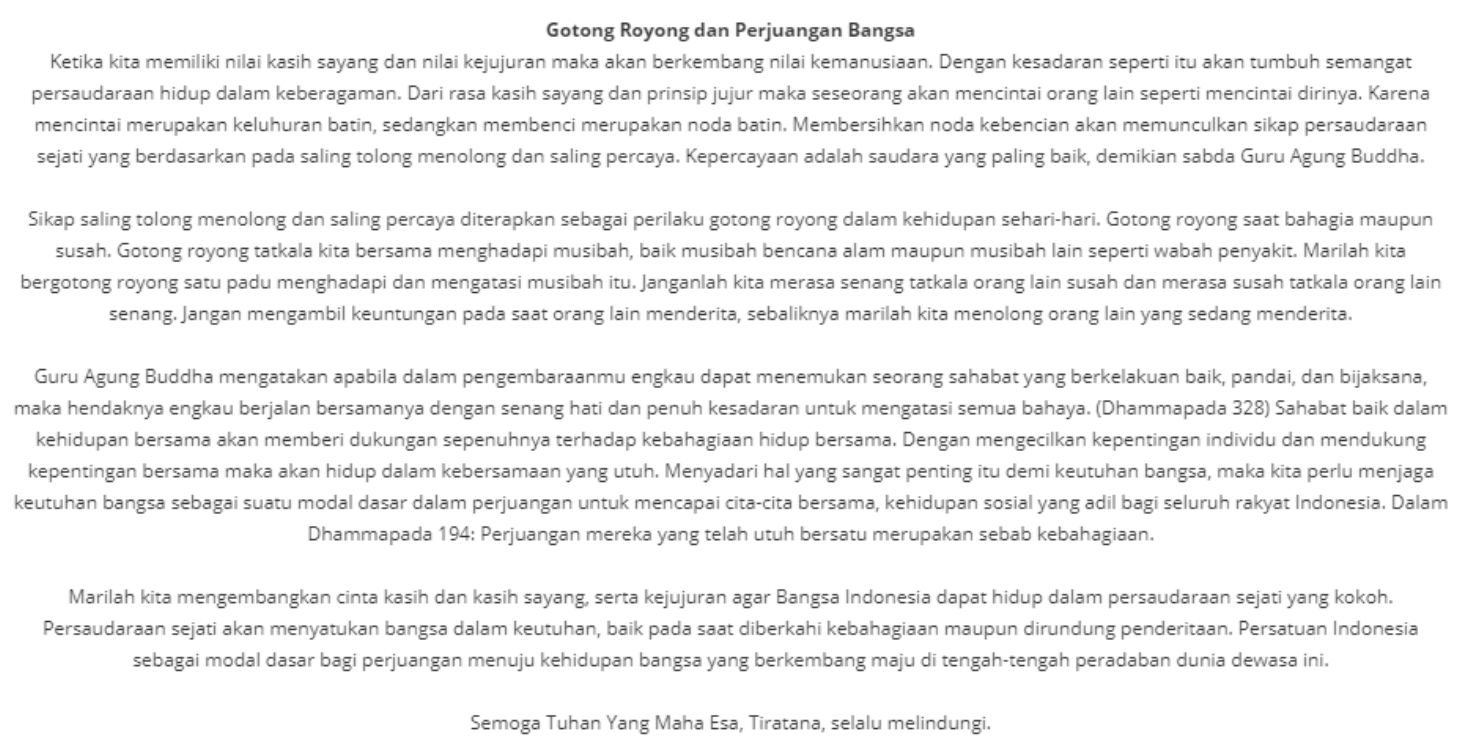

Source: 2020 Vesak Message of Sanggha Theravāda Indonesia, (2020).

Picture 4. Subheading "Mutual Cooperation and The Nation's Struggle" in the 2020 Vesak Message of Sangha Theravāda Indonesia

Table 3. The results of the analysis of the subheading "Mutual Cooperation and The Nation's Struggle" in the 2020 Vesak Message of Sangha Theravāda Indonesia for the Mutual Cooperation section

\begin{tabular}{|c|c|c|c|}
\hline No. & Pieces Digest Paragraphs & Buddhist Semiotics & $\begin{array}{c}\text { Buddhist Communication } \\
\text { Theory }\end{array}$ \\
\hline 1 & $\begin{array}{l}\text { When we have the value of } \\
\text { compassion and honesty then the } \\
\text { value of humanity will develop. From } \\
\text { compassion and honest principles, } \\
\text { one will love others as if they love } \\
\text { themselves, thereby removing the } \\
\text { stain of hatred in the mind. }\end{array}$ & Syntactic System & $\begin{array}{l}\text { Peace and harmony as the } \\
\text { pillars of the ideals of } \\
\text { society. }\end{array}$ \\
\hline 2 & $\begin{array}{l}\text { Mutual cooperation when dealing } \\
\text { with disasters, both natural disasters } \\
\text { and other disasters, is a real example } \\
\text { of practice in life. Do not feel happy } \\
\text { when others suffer, on the contrary, } \\
\text { we should help others who are }\end{array}$ & Implementation & $\begin{array}{l}\text { All forms of violence must } \\
\text { be eliminated. }\end{array}$ \\
\hline
\end{tabular}


suffering.

Referring to table 3 on the previous page, part of this subheading discusses mutual cooperation in terms of Buddhist teachings which are divided into two main pieces with more specific meanings. Then it is reviewed from two elements in Buddhist semiotics, namely the syntactic system and implementation, then each of these points is associated with Buddhist communication theory.

The syntactic system is a branch of linguistics that examines the intricacies of discourse, sentences, clauses, and phrases (Ramlan, 1997); and as a study of the patterns needed as a means to connect words into sentences (Radford, 1997). The syntactic study includes the object of the study of phrases and sentences from various aspects, namely syntactic construction, types of phrases, and structures.

The essence of the first point paragraph tells that the emergence of human values comes from the value of compassion and honesty so that you can love others as you love yourself. The syntactic analysis of Buddhist semiotics in this text explains the relationship between the cultivation of compassion and honesty as the basis for humanitarian practice between others and doing good for the benefit of many people.

Spreading the message of goodness according to reality to the wider community is the responsibility of every member of the community so that everyone can live safely and happily. Every action we take, must be done with a clear understanding and without doubt and based on goodness where having full awareness as the root of the action also plays an important role so as not to do bad things.

In one of the Buddhist teachings regarding the welfare of the nation, it is stated that there are seven conditions conducive to the growth of the welfare of the nation, among which citizens must gather to carry out deliberation in harmony, reach consensus together to resolve their national affairs, and comply with applicable laws. By upholding respect for the teachings of truth like this, it can also reduce disputes and misunderstandings, both small and large, and make society more peaceful and orderly as a support for the achievement of common goals.

In the essence of the second paragraph, it explains how to live to help each other and trust each other to be applied as mutual cooperation behavior in everyday life. This is seen as an implementation of Buddhist semiotics to show that helping others indirectly also practices the teachings of love and human values at the same time.

Also showing empathy for the suffering of others will be able to ease the mental burden so as to support them to quickly get up and achieve their goals. Help morally as advice and discourse become one of a small but significant form of great help, as can also be seen live in harmony with their fellow community members.

Most people just devote a sincere affection to family members, friends, kin only and this is the usual practice of affection to a loved one. This practice should be extended to all beings in the universe so that more beneficiaries goodness.

All forms of violence that are both verbal and non-verbal must be removed because it does not correspond to the norms and rules of the doctrine of universal truth. This practice in 
addition to eliminating lust, greed, and personal hatred also gains rewards that result in the creation of harmonization of life with others and can lead to the supreme liberation.

Table 4. The results of the analysis of the subheading "Mutual Cooperation and The Nation's Struggle" in the 2020 Vesak Message of Sangha Theravāda Indonesia for the The Nation's Struggle section

\begin{tabular}{|c|c|c|c|}
\hline No. & Pieces Digest Paragraphs & Buddhist Semiotics & $\begin{array}{c}\text { Buddhist Communication } \\
\text { Theory }\end{array}$ \\
\hline 1 & $\begin{array}{l}\text { Good friends who live together will } \\
\text { wholeheartedly support happiness } \\
\text { because knowing this is important for } \\
\text { the integrity of the nation. We must } \\
\text { maintain the integrity of the nation as } \\
\text { a prerequisite for fighting for } \\
\text { common goals in a just social } \\
\text { environment for all Indonesian } \\
\text { people. }\end{array}$ & Logical Semamtics & $\begin{array}{l}\text { Perjuangan mereka yang } \\
\text { telah utuh bersatu } \\
\text { merupakan sebab } \\
\text { kebahagiaan }\end{array}$ \\
\hline
\end{tabular}

Source: Research Processing Results, (2021).

In table 4 above, it can be seen that this is part of this subheading which discusses the struggle of the nation based on Buddhist teachings. Where the essence of this paragraph can be viewed from the elements of Buddhist semiotics, namely logical semantics, it will then be associated with Buddhist communication theory.

Trismanto (2015) reveals that the preparation of a logical sentence is closely related to the truth of the sentence itself because it also depends on the proposition. The meaning of a sentence greatly determines the level of logic, therefore in compiling sentences it is necessary to pay attention to the choice of words (diction), use of words, and conjunctions so that the meaning of the message can be conveyed properly.

Digest on the subheading have revealed the importance of awareness will be the main foundation of happiness together in the struggle to achieve common goals and create social justice for all human society. The interpretation of the Buddhist teachings contained in verse 194 in the Dhammapada scriptures shows that happiness can be achieved when the struggles of everyone who practice good practices have united, but also for the sake of maintaining the integrity of the nation.

The struggle of every citizen who has been united in maintaining the unity and integrity of the nation must be appreciated by all groups so that this country can be passed on to the next generation with good conditions. Full support from good friends (kalyānamitta) like this is very necessary to be able to give happiness to live together by putting aside personal interests for the welfare of living in a complete togetherness.

Gotama Buddha has a very impressive communication technique in conveying His teachings to everyone from nobles to commoners so that the meaning conveyed can be well received and practiced to this day. He can conquer those who are evil without violence but 
only by practicing the truth and practicing love so that he can increase the goodness in the universe (Littlejohn \& Foss, 2012).

By relying on the kindness and human values, the Buddha teaches tolerance with fellow human beings and even to different religious beliefs in order to maintain harmony in social life. Regardless of social strata, this teaching of truth is always conveyed with a different approach but still with the same meaning so that the teaching can be practiced by anyone.

Simplicity in life as a form of expression of love that includes a reorientation of one's views and behavior, even in a competitive world, full of lust and full of attachment. Someone who has a gentle nature of his life simple, effective and efficient, and has no restrictions on its senses, not excessive and uncontrolled manner will be easy to cultivate wisdom so that it can perform useful actions and does not harm others.

Seeing a life full of suffering both physically and mentally as a fact of life that cannot be avoided by everyone, such as birth, old age, illness, to death. Through the message of peace that has delivered the Buddhist doctrine which teaches us that this good practice can bring whoever they put it into practice to achieve the highest goal in Buddhism is an absolute exemption (nibbāna).

The findings based on the review of four previous section shows that the model of communication in the Buddhist influence on a person's life in the community. For example, blending in with the local culture in Indonesia, especially Java culture so now Borobudur can stand as a form of acculturation with the universal teachings of Buddhism and Buddhist convey to the general public through the carved reliefs on the walls.

The meaning conveyed in the text of the 2020 Vesak Message by Sangha Theravāda Indonesia focuses on harmonization in life to jointly build the integrity of the nation, which can be realized by understanding each other, increasing tolerance, caring for each other, forming a sense of love so that they can live like brothers. These universal teachings can be practiced by every individual in the midst of the diversity that exists in Indonesian society.

\section{CONCLUSION}

Communication in Buddhist teachings is unique in conveying messages of kindness to all individuals regardless of social strata so that it is easily accepted and practiced, one of which is the development of the concept of Humanistic Buddhism which can be a solution to every human problem. Gotama Buddha uses a distinctive style of communication to teach various teachings of goodness and can even subdue those with bad intentions into entering the path of truth.

Moving on from the Buddhist view of the reality of life which consists of impermanence, suffering, and without essence, the text of the 2020 Vesak Message delivered by Sangha Theravāda Indonesia opens our insight into the true nature of life and sees things not only from one side. There needs to be wisdom in understanding the reality of life to finally be free from suffering.

In addition, tolerance in the diversity of society is one of the Buddhist teachings that is very relevant to the current state of the Indonesian people, where with mutual respect we can live peacefully side by side and harmoniously so that national unity can also be maintained. 
Prioritizing the public interest over individuals or groups will produce results that are in accordance with community expectations and all human beings can feel the same benefits.

The practice of Buddhist values including mutual cooperation, spreading the seeds of love, supporting good friends (kalyānamitta) to always do good is a form of forming a spirit of brotherhood in the midst of pluralism in Indonesian society, so that it can be used as a foundation for the integrity of the nation. Many Buddhist literature sources raise the theme of teachings to be applied in social life by not forcing Buddhism on those of different faiths, but to live side by side together to achieve social goals, such as prosperity, harmony, and so on.

Likewise, the text of the 2020 Vesak message of Sangha Theravāda Indonesia has a communication model in accordance with the Buddhist view by inviting us Buddhists as citizens to practice Buddhist teachings and return to brotherhood to jointly maintain the integrity of the nation and at the same time maintain harmony and peace in the social environment. society, so that it is hoped that the practice of this truth can be maintained until the next generation in the future.

\section{REFERENCES}

Anggraini, R. Y. (2017). Masuknya Paradigma Interpretif pada Kajian Ilmu Akuntansi. Jurnal Analisa Akuntansi Dan Perpajakan. https://doi.org/10.25139/jaap.v1i1.101

Bahrum. (2013). Ontologi, Epistimologi, dan Aksiologi. Sulesana.

Dzakie, F. (2014). Meluruskan Pemahaman Pluralisme Dan Pluralisme Agama Di Indonesia. Al-AdYaN.

Faridah, I. F. (2013). Toleransi Antar Umat Beragama Masyarakat Perumahan. KOMUNITAS: International Journal of Indonesian Society and Culture. https://doi.org/10.15294/komunitas.v5i1.2368

Fauzi, E. P., \& Fasta, F. (2020). Modern Muslimah in Media : a Study of Reception Analysis in "Saliha" Program on Net Tv. Aspiration.

Germer, K. C., \& Siegel, R. D. (2012). Wisdom and compassion in psychotherapy: Deepening mindfulness in clinical practice. Guilford.

Ginting, H., \& Ginting, A. (2019). Beberapa Teori Dan Pendekatan Semantik. Issn, 2(2), 7178. https://core.ac.uk/download/pdf/276535609.pdf

Guangliang, L. (2019). Humanistic Buddhism and It's Humanization, Modernization, and Incorporation into Daily Life. Studies on Humanistic Buddhism II: Practical Application 人間佛教論文選要， $\quad 2, \quad 1-6 . \quad$ https://journal.nantien.edu.au/wpcontent/uploads/2019/09/01-li-guangliang_humanistic-buddhism-and-itc2b0c2b6sc2b0c39fhumanization-modernization-and-incorporation-into-daily-lifec2b0c2ae.pdf

Hamdun, D. (2018). Pendidikan Keluarga Sebagai Manifestasi Basic Nilai-Nilai Pluralisme di Dukuh Kalipuru Kendal. Al-Bidayah: Jurnal Pendidikan Dasar Islam. https://doi.org/10.14421/al-bidayah.v9i2.12

Januarti, \& Wempi, J. A. (2019). Makna Tenun Ikat Dayak Sintang Ditinjau Dari Teori Semiotika Sosial Theo Van Leeuwen. Bricolage: Jurnal Magister Ilmu Komunikasi, 5(01), 073. https://doi.org/10.30813/bricolage.v5i01.1743

Jumsai, A.-O., \& Na-Ayudhya. (2008). Model Pembelajaran Nilai Nilai Kemanusiaan 
Terpadu: Pendekatan yang Efektif Untuk Mengembangkan Nilai- Nilai kemanusiaan atau Budi Pekerti pada Peseta Didik. Yayasan Pendidikan Sathya Sai Indonesia.

Kadir, A. R. (2014). Umat Minoritas dalam Pelayanan Kementerian Agama: Menyasar Penganut Agama Budha di Kota Jayapura Provinsi Papua. Jurnal "Al-Qalam."

Kattsoff, L. O., \& Soemargono, S. (1986). Pengantar filsafat: sebuah buku pegangan untuk mengenal filsafat; alih bahasa, Soejono Soemargono. Tiara Wacana.

Koli, N., \& Sadono, T. P. (2018). Memahami Makna Solidaritas (Telaah Semiotika Roland Barthes pada Aksi Solidaritas “1000 Lilin”, Harian Kompas, Edisi Sabtu, 13 Mei 2017). Bricolage: Jurnal Magister Ilmu Komunikasi. https://doi.org/10.30813/bricolage.v3i02.923

Lane, K., Chandler, E., Payne, D., \& Pomeroy, V. M. (2020). Stroke survivors' recommendations for the visual representation of movement analysis measures: a technical report. Physiotherapy (United Kingdom). https://doi.org/10.1016/j.physio.2019.08.008

Littlejohn, S., \& Foss, K. (2012). Encyclopedia of Communication Theory. In Encyclopedia of Communication Theory. https://doi.org/10.4135/9781412959384

Marta, R. F. (2017). Refleksi Hibriditas Budaya dalam Pancasila pada Realitas dan Media sebagai Identitas Bangsa. Bricolage: Jurnal Magister Ilmu Komunikasi. https://doi.org/10.30813/bricolage.v3i01.841

Mulyadi, M. (2013). Penelitian Kuantitatif dan Kualitatif serta Pemikiran Dasar Menggabungkannya. Jurnal Studi Komunikasi Dan Media. https://doi.org/10.31445/jskm.2011.150106

Mulyana, D. (2007). Komunikasi, Suatu Pengantar. Remaja Rosda Karya.

Nidyansari, D. A. (2018). Ketidakharmonisan Komunikasi dalam Keluarga pada Pembentukan Pribadi Anak (Pendekatan Humanistik). Jurnal Riset Komunikasi. https://doi.org/10.24329/jurkom.v1i2.39

Nurgiyantoro, B. (2010). Teori kajian fiksi. BPFE.

Pornchai Sripakdee, P. (2017). The Role Of Buddhist Ethics And Communication In The Contemporary World Crisis. Vidyottama Sanatana: International Journal of Hindu Science and Religious Studies, 1(2), 155. https://doi.org/10.25078/ijhsrs.v1i2.319

Radford, A. (1997). Syntax: A Minimalist Introduction. In Syntax A Minimalist Introduction. Ramadani, F. (2020). Hakikat Makna dan Hubungan Antar Makna dalam Kajian Semantik Bahasa Arab. Taqdir. https://doi.org/10.19109/taqdir.v6i1.5500

Rambelli, F. (2013). A Buddhist Theory of Semiotics: Signs, Ontology, and Salvation in Japanese Esoteric Buddhism. In Bloomsbury Academic (1st ed.). Bloomsbury Academic. https://doi.org/10.5040/9781472541840

Ramlan, M. (1997). Ilmu Bahasa Indonesia: Sintaksi. CV Karyono.

Richard L. Kimball. (2000). Humanistic Buddhism as Conceived and Interpreted by Grand Master Hsing Yun of Fo Guang Shan. Hsi Lai Journal of Humanistic Buddhism, 1, 1-52. http://buddhism.lib.ntu.edu.tw/FULLTEXT/JR-JHB/jhb94214.htm

Rorong, M. J. (2020). Simbokronik Komunikasi. Jurnal Masyarakat Dan Budaya. https://doi.org/10.14203/jmb.v22i3.883

Roy, S., \& Narula, S. (2017). Alternative Views on the Theory of Communication: An 
Exploration through the Strands of Buddhism. Journal of Mass Communication \& Journalism, 07(06). https://doi.org/10.4172/2165-7912.1000354

Sankey, M. D. (2006). A neomillennial learning approach : Helping non - traditional learners studying at a distance. International Journal of Education and Development Using Information and Communication Technology.

Saputera, B. A. (2014). Perbedaan Model dan Teori dalam Ilmu Komunikasi. Humaniora. https://doi.org/10.21512/humaniora.v5i2.3255

Susilawati, Y., \& Ekwandari, Y. S. (2012). Persepsi Umat Buddha Pada Drama Waisak Di Vihara Manggala Ratna Desa Sumbersari Kecamatan Sekampung Kabupaten Lampung Timur. 1-11.

Sya, M., Marta, R. F., \& Hadi, I. P. (2020). Refleksi Pluralisme Melalui Film Animasi Si Entong Sebagai Identitas Budaya Indonesia. Jurnal Riset Komunikasi. https://doi.org/10.24329/jurkom.v3i1.102

Tan, P. (2014). Buddhism For The Global Benefits and Its Challenges in Modern Times. Conference: Presentation Paper on 11 July 2014, World Buddhist UniversityAt: Thailand, July, 1-13.

Tobgay, T. (2018). Buddhist Contributions to Human Development. 15th Vesak Day in Mahachulalongkornrajavidyalaya University Conference Hall, Ayutthaya, Bangkok, Thailand, $1-14$. http://himalaya.socanth.cam.ac.uk/collections/journals/jbs/pdf/JBS_38_01.pdf

Trismanto. (2015). Berbahasa Dengan Logika. Serat Acitya - Jurnal Ilmiah UNTAG Semarang, 1, 46-51.

Website Resmi Sañgha Theravāda Indonesia. (2020). Pesan Waisak 2564/2020 Sañgha Theravāda Indonesia. Medkom Sangha Theravāda Indonesia. https://sanghatheravadaindonesia.or.id/index.php/component/content/article/27blog/food-and-recipes/100-pesan-waisak-2564-2020?Itemid=101

Zainnudin, H. M. (2013). Ontologi. UIN Malang. https://www.uinmalang.ac.id/r/131101/ontologi.html

Zengwen, Y. (2019). The Future of Humanistic Buddhism. Studies on Humanistic Buddhism II: Practical Application 人間佛教論文選要，促，23-47. https://journal.nantien.edu.au/wp-content/uploads/2019/09/04-yang-zengwen_thefuture-of-humanistic-buddhism.pdf 